\title{
Engineering Education in Iberian America
}

\author{
Melany M. Ciampi \\ President of Safety, Health and Environment Research Organization and Vice President of International Society for \\ Engineering Education - IGIP, Brazil, melany@copec.org.br \\ Claudio da Rocha Brito \\ President, Science and Education Research Council, Brazil, cdrbrito@copec.org.br \\ Rosa Vasconcelos \\ President, President of Academic Council of University of Minho, Portugal, rosa@det.uminho.pt \\ Maria Feldgen \\ President, IEEE Ed.Soc Argentina Chapter, Argentina, mfeldgen@ieee.org \\ Edmundo Tovar \\ Director, Universidad Politécnica de Madrid, Spain, etovar@fi.upm.es
}

\begin{abstract}
The large Continent of America has in its territory besides overseas regions, dependencies and colonies 35 sovereign countries, 25 in North America and 12 in South America. Among them there are two big countries Brazil, which official language is Portuguese and Argentina, which official language is Spanish. Both are of political and economical importance in South America. They both belong to the so called Iberian America, which is a term used since the second half of the 19th century to refer collectively to the countries in the Americas, which were formerly colonies of Spain or Portugal. The Iberian countries in Europe are Portugal, Spain, Andorra and Gibraltar. The objective of this paper is to present the history and he current status of engineering education in Iberian America countries Brazil and Argentina followed by the countries that originated the engineering education in these countries, Portugal and Spain.
\end{abstract}

Index Terms - Bologna process, policy makers, public school, polytechnic schools, university schools.

\section{INTRODUCTION}

It is of great importance the discussions about engineering education in different geographical parts of the world. It is a way to promote and increase awareness of contemporary engineering education efforts and at the same time to explore the views of young people, teachers, engineering lecturers and policy makers from other parts of the world. The organization of such panel Engineering Education in Iberian America is important to bring teachers, researchers and engineering lecturers together to discuss and to think over the different ways engineers are formed. It will contribute for the development of innovative engineering curriculum in order to increase the numbers of young people entering engineering.
Following there are texts about education in the 4 countries with the objective of informing briefly about how education has developed in the countries separated by the Atlantic but sharing common cultural roots, the issues faced by the countries and the perspectives for the future.

The real discussions will be developed during the panel session that counts with high level lecturers, very well informed and involved with engineering education in their respective countries. They will bring updated information and the framework adopted to defeat the present obstacles and demands in order to face the 21 st educational crisis.

\section{DISCUSSIONS ABOUT EDUCATION IN BRAZIL}

Brazil Superior Education has a history of success that has been encountering some problems of social and financial order. And it starts with the creation of Public Universities in the many states of the country, which have worked very well for many years; the Country has achieved and has built a solid reputation even abroad also creating generations of Brazilian scientists and educators. In that aspect, there is still a long road to travel, involving three agents: the State, that has to generate and to apply public politics of science and technology, besides financing them; the University, to which fits to form qualified personnel and to create basic science; and the Industry, that should invest in the technology creation, besides accomplishing applied research, to incorporate qualified personnel and, this way, to win competitiveness.

With the creation of Public Universities in the many states of the country, which have worked very well for many years, the country has achieved and has built a solid reputation even abroad also creating generations of Brazilian scientists and educators [1]. These people fortunately have refused to accept the ominous and narrow-minded neoliberal policies for education having started a fighting to keep up the achievements already gotten and actions that help to maintain and to enhance the researches in every field

October 12 - 15, 2011, Rapid City, SD 


\section{Session S4A}

of science and technology. Valuable discussions at national level during conferences, all communication Medias like radio, $\mathrm{TV}$, etc took place for many years and still takes place and it may seem to be lonely fight once economical speculations seems to be more powerful with more sharp actions world wide [2].

Despite all the problems, professionals and educators of every field of science and technology have been discussing the destiny of education in the country taking into account the historical moment of the world. Certainly some of these discussions have generated some practical actions at governmental level as a response to the society that see itself as the most interested part in the issue. In Brazil in engineering and technological fields the situation is very delicate. Although the proliferation of private universities all over the country expanding the number of 3 rd grade students it does not assure the increase of students in engineering and technology areas. The Present Status of Engineering Education.

In order to understand the present situation of teaching in Brazil it is important to know something about the direction of public policies to education adopted with the objective of democratizing the teaching. These policies present two important points [3]: the Sampaio Doria Reform made in 1920 and the Expansion of Junior High School implemented in the period 1968-70.

\section{ENGINEERING HISTORY IN BRAZIL}

Engineering history in Brazil started with the military engineering, which military actions at that time in the country were basically the construction of fortifications and the seek of solutions for defense and attack evolving what is today the civil engineer.

The colonization of Brazil plus the insurance aspect of Portugal made the royal government to recognize the necessity of forming the national engineer and so it became of crucial importance. It was made attending the evolution of French Schools of Engineering and so in 1641 in Lisbon born the Artillery and Square Classes becoming in 1647 the Special Class of Fortification and Architecture. The Portuguese engineer Luiz Serrão Pimentel (1579-1613) managed the school and it is considered the starting point of Lusitanian-Brazilian engineering.

Portuguese style of construction can be seen everywhere in Brazil and the engineering schools still keeps the European schools style obviously because of the great influence of its countries along the colonization process. The evolution of engineering in Brazil follows very close the world trends. From the construction of Fortifications through electrical engineer to what is called today Mechatronic engineering it has been developed in according to the necessities of promoting the development of the Country seeking for the best applications of sciences achievement to the local resources.

Many accomplishments of big proportions can be seen through the time, not only public buildings and houses but also practical applications of electricity like telegraphy, telephony and lighting. The insertion of electrical energy in Brazil happened in the same historical moment of industrial expansion and development of developed countries. Since the Fortification Classes and Military Architecture founded in Bahia, in 1699 until more than 200 engineering schools, engineering education has had a history of success full of many conquests and accomplishments [4].

\section{THE Role OF ENGINEERING IN SCIENCE AND TECHNOLOGY}

Brazil is five hundreds years old with a history of races meeting to the construction of a peoples' identity marked by the diversity and cultural richness. Five hundred years that brings the challenge of starting this new millennium building up a new Brazil, a Country where quality of life in daily basis is a concept of its 166.113 .000 in habitants and not only of a minority. Having a look at the present history of humanity it is easy to notice the importance of engineering and engineers in the development of science and technology, which have shaped a new social world order having as a straight consequence the new life style and so a new way of thinking.

Recognizing the importance of engineering in world scenery Brazil has been working to get the competitiveness of national goods and services by means of incentive to create projects of qualification of professionals through continuing education for example and others. Many representative groups, leaderships and agencies have been implemented programs to prepare the engineers to increase the efficiency of research system, experimental development, engineering, producing system and market [5].

All these efforts have been having a kind of smooth effect once it is one of the most difficult programs of College level and also expensive that does not help very much the inclusion policy. However some Colleges have opted for a softer engineering program offering them in the evening. These programs are lighter and more focused in technical knowledge and less focused in basic sciences. The students in general work all day and choose engineering programs because it is a way to be promoted at work. A third degree diploma opens some doors, it means not only the possibility of earn more money but also to reach an upper status, socially speaking. It is a fact that even being a lighter program for the students it is very hard and in general it takes them more than five years to finish it. The diploma has the same value of a program that prepares engineers of conception. In certain way it helps the inclusion policy of education although the number of engineers has been decreasing considerably in the last 10 years.

\section{ANTECEDENTS OF ENGINEERING EDUCATION IN Portugal}

Until the nineteen seventies, the following aspects characterized technical teaching in Portugal:

- Exclusive State responsibility, that centralized, financed and defined course programs;

978-1-61284-469-5/11/\$26.00 C2011 IEEE

October 12 - 15, 2011, Rapid City, SD

\section{$41^{\text {st }}$ ASEE/IEEE Frontiers in Education Conference}


- Weak specialization in technical university courses, with a strong common training component verified in all courses;

- Reduced dimension and concentration of Engineering Schools, which only existed in Lisbon and Porto;

- Dichotomy teaching, based on a hierarchical and exclusive model (since it defined who could be and who could not be an engineer) and by the fact that its output resulted in an inverted labor force pyramid.

New engineering university courses were established in Coimbra, Braga, Aveiro, Lisbon and a few other places from 1972 onwards.

At the beginning of the nineteen seventies, polytechnics were integrated into the higher education system, awarding a bachelor degree with the possibility of obtaining a licentiate degree, in the event students carried out a period of special study. So, technical agents began obtaining a bachelor's engineering degree, and receiving the professional title of technical engineers. European integration reinforced the growth of higher education in Portugal, which was achieved through rapid democratization and quantitative, and mainly legislative, changes.

In 1986, a binary separation of the higher educational system was established in Portugal, through the Education's System Basic Law, which integrated higher education engineering institutes into polytechnic teaching in 1988.

In 1988, the Law concerning University Autonomy was also approved. Through this Law, universities were defined as centers for the creation of culture, science and technology transmission and diffusion, which, through their expression of study, teaching and research, enabled them to perform their role in society.

At the end of the nineteen nineties, two phase courses appeared which gave polytechnics the possibility to confer bachelor and licentiate degrees. In this context, the tendency for a greater standardization of technical higher education seems clear, with differentiation between polytechnic and university courses only for post-graduate and research activities. Curricula differentiation of polytechnics and universities could only be achieved through the accreditation process provided by the professional engineers' association.

The evaluation of the science and technology system, carried out in 1996 and 1999, confirmed the need to promote connections between research centers, civil society and companies, as well as the need to promote scientific cooperation at the level of national and international mobility [6].

\section{Some Remarks about the Bologna Process}

When analyzing engineering education today in Portugal (and in Europe) the Bologna process must be mentioned. It is likely to be a unique chance for Europe to modernize its higher education, according to the same principles, with a perspective of reaching a new level of understanding and readability. It has touched off an impressive set of reforms.
Nevertheless it must be admitted that the Bologna process may give rise to various criticisms:

- It implicitly links itself to a singular model of higher education (following the same rationale and being directed by the same values);

- It has been designed without considering the reality of the job market (top-down policy);

- It seems to have taken its inspiration from the North American model, which could provide a certain guarantee, but appears indeed to be following a very different path.

For these reasons, which should inform an open and critical debate, the application of the Bologna principle should remain very pragmatic and open to other dimensions, such as:

- The importance of having a limited number of universities in a position to be competitive at the world level;

- The importance of placing some universities, with credible expertise and know-how, in some fields the so-called technological clusters;

- The importance of keeping a high level of flexibility and response, to launch new types of programs.

In most European countries a distinction has been made throughout history between a scientifically oriented syllabus and a more practically oriented syllabus. Strictly following the Bologna guidelines could lead to a complete reformulation of the educational system on new bases. The examples of Sweden, the Netherlands and to a certain extent Germany show a more pragmatic approach, with a willingness to reconcile the Bologna principles and a lengthy tradition.

Mobility of students to or from other countries is considered an important goal according to Bologna. In the case of Portugal, some difficulties occur related to the language now used in the engineering courses (Portuguese). Teaching the Master courses in English, as in Norway, could be a positive opportunity [7].

\section{UNCONTROLLED EXPANSION OF UNIVERSITIES AND Polytechnics}

In Portugal, Polytechnics and Universities had different beginnings and have different backgrounds. Even if in some, rather few cases, the objectives at the beginning might have been the same their evolution almost always resulted in quite different approaches of teaching at the higher level.

It is common to separate two general profiles of engineers, corresponding to the two types of degrees existing in most European countries: a first profile whose major concern is to master existing technologies and to use them as efficiently as possible; a second profile whose main objectives are to develop a capacity for a critical perspective concerning existing solutions and an ability to set up new ones, in most cases with an important use of scientific resources and conceptual models. 


\section{Session S4A}

Polytechnics (the first profile) are more geared towards the maintenance and/or production engineer. Universities (the second profile) aim at the concept engineer.

Both types of engineers are required by the economy, even if, in Portugal, the number of University graduate engineers has been higher than those graduating from Polytechnics, in striking contrast to perceived economic needs.

There should preferably be enough institutions of higher education to ensure that they are available to students with the relevant educational qualifications. Hence, it is positive to have higher engineering schools in various geographical locations of the country. However, the number of Polytechnics and Universities must be limited such that the financial situation allows them to possess good quality in their various fields of research and education. It is not desirable to have too many higher engineering schools since this will inevitably lower the quality - unless they are given the appropriate financial support from the government. On the other hand it is well known how difficult is to stop the proliferation of Polytechnics and Universities, because of social pressures and interests of politicians.

Universities, in particular those that are research-based institutions, should probably remain limited in number, as an opportunity for Portuguese education to be present and active at the front of new knowledge, with an emphasis put on maintaining an outstanding international ranking.

However, there is no optimal size in general. Each activity obeys to a different equation (without speaking of the cultural context):

- an interactive pedagogy is not possible if the class is too large;

- a community of professors has a higher level of interactivity;

- strategic initiatives are difficult if the size is not large enough;

- political visibility can be attained through size or through the high status of the responsible individuals [8].

\section{IS THE EXISTENCE OF A SMALL NUMBER OF UNIVERSITIES WITH GUARANTEED QUALITY THE BEST WAY TO ENSURE COMPETITION AMONG UNIVERSITIES?}

While there should be enough universities to enable students - with the relevant educational qualifications - from the whole country to have access to higher education, the financial support the universities get is crucial for the quality they can ensure in research and in education. If there are too many universities in a country, the resources will be limited for each institution and the quality risks dropping. It is better to focus money and qualified teachers, researchers and students on fewer universities to ensure high quality and good results.

Quality is a basic element of University excellence. However, having a small (fixed) number of Universities with guaranteed quality it is dangerous. It is not good that Institutions rely on their "degree of quality". They should continuously strive to improve themselves and achieve the desired level of quality.

It is also quite difficult to detect "quality Universities". Institutions will have some prominent areas, but they will not be excellent in all subjects. It seems better to identify "quality Masters", or "quality Departments" instead. These nominations should be the result of periodic evaluations, and they should only be valid for a period of a few years. They should be accompanied by a significant budget increase and with a number of goals to achieve in the next fixed chronological period.

Quality of persons is a decisive factor. Results will be bad even with good financial support and good organization, if the quality of the persons involved falls below expectations. How to get gifted professors and students is a critical question, but solutions are not obvious: money, social status, interest...?

Human nature tries to avoid competition and especially harsh competition. Public Authorities have, through various measures, to ensure that competition is alive (that may be partly contradictory with the choice of elite universities).

Quality insurance appears useful and necessary, as soon as institutions have a high level of autonomy. But experience shows that the bulk of the work is done through selfevaluation (internal culture), and that accreditation procedures or quality assessment may become obstacles to innovative approaches.

To preserve the special focus of application in the training of engineers, and on the scientific aspect at the institutes of technology and universities, any proposals that could enhance opportunities to produce excellent university teachers with industrial experience have to be supported. The culture of co-operation between academic institutions and industry deserves continued support.

A critical point is curiosity concerning developments in other countries and interest in taking the benefits of good practices. An attitude which regularly asks for external (foreign) experts to evaluate the national situation is wise, especially for smaller countries. Sweden is a good example of this attitude, but it is now common to rely on international expertise [9].

\section{The Paradigm of The State SCHOOL In ARgentina}

The nationalization of education systems was a founding flam updating and emerging state of pedagogy.

For the construction of the nation state, the school would play a significant role. In other words the state stands as guarantor of the utopia that educators have been preaching for several centuries but had not yet been achieved: the ideal pansophic; "teach everything to everybody".

Education is therefore configured as a reason of state. A slow process of nationalization starts to develop from the late nineteenth century and consolidated around the execution of a series of tactical strategies, namely: Teacher Recruitment, Laicism, Compulsory education. 


\section{Session S4A}

This arrangement, were due mainly to two factors: first, the detection of childhood body demographics' resulting from changes due to the industrial revolution. And the second, to address the problem of childhood that makes its appearance that is, those children who were abandoned to idleness marginalized from schooling.

The requirement necessarily entailed a partner: free education, so that it is accessible to all sectors and contributed to the progress of lower income classes [10].

\section{Higher Education of ENGineERING IN ARgENTINA}

Throughout Argentina's history, the teaching of science and distinctive engineering-related technical has historical vicissitudes which have been encouraged, discouraged or challenged from their teaching methodology. The tension between the theoretical and practical training has always been present.

In XIX century, in the revolutionary period that led to independence, the practice of engineering was linked with the Spanish military engineering. In 1821 it was created the University of Buenos Aires and the first mathematical studies related to engineering education, but not formally a career. Bernardino Rivadavia then hired civil engineers to the first European source for infrastructure development and in 1825 Juan Maria Gutierrez graduated from the Metropolitan University Surveyor. In 1866, the University of Buenos Aires fosters the creation of the Civil Engineering and from that came the first class in 1870.

In the last decade of the twentieth century, many universities were institutionalized in the Greater Buenos Aires. Engineering programs were created fully designed taking into account the technical characteristics of the social and humanistic training of engineers. Also in higher education in Argentina, incorporated a number of important private universities in the system management.

Currently engineering training is by University Education and its securities are regulated by the state and that their actions are in the public sphere [11].

Engineering enrollment, a profession of men:

\begin{tabular}{|l|l|}
\hline Men & \\
\hline Women & \\
\hline
\end{tabular}

Both students and new students enrolled, as graduates shows a tendency for each 5 students studying engineering 4 of them are male.

Engineering degrees offered in the country are as follows: Aeronautical Engineering; Environmental Engineering; Food Engineering; Surveying Engineering; Biomedical Engineering and Bioengineering; Civil Engineering; Electrical Engineering; Electromechanical Engineering; Electronic Engineering; Hydraulic Engineering; Industrial Engineering; Materials Engineer; Mechanical Engineering; Metallurgical Engineering; Mining Engineering; Nuclear Engineering; Petroleum Engineering; Chemical Engineering; Telecommunications Engineering; Systems Engineering; Naval Engineering; Engineering
Geodesy and Geophysics; Agricultural Engineering; Forester [12].

\section{THE SPANISH UNIVERSITY SYSTEM}

There are three levels of university degree, valid throughout Spain.

First stage degrees, lasting three academic years and leading to the degree of Diploma, or Technical or Engineering Technician.

First and Second Stage degrees, lasting 4, 5 or 6 years and leading to the degree of Graduate. Second Stage only degrees, lasting two years and open to holders of a diploma or to students who have successfully completed the first stage of a First and Second Stage Degree, in other words, who have completed the first two years of four-year degrees, or the first three years for five year degrees. On completion of studies, the degree of graduate is awarded. Doctoral. These are the so-called Third Stage courses, on whose completion, and once the doctoral thesis has been defended successfully, the degree of Doctor is awarded. Doctoral courses comprise 32 credits ( 1 credit $=10$ hours), distributed into two periods: the taught period ("docencia") (20 credits) and the research period (12 credits).

The University's own titles and postgraduate degrees are not official, although most universities offer such courses: masters, diplomas, specialization courses, Spanish courses for foreigners, and so on [13].

The Spanish university system dates back to the Middle Ages. The oldest among Spanish Universities is Salamanca, founded in 1218. The present system, however, is actually descendant of the 19th century liberal university, inspired by the centralized French model. In the last years, it has experienced its greatest growth in history, while at the same time advancing towards a self-governing and decentralized system.

Higher education is provided by both public and private institutions. Universities are divided into departments, university colleges, superior technical schools, university schools, university institutions, and other centers, notably the university schools [14].

The following official degrees can be obtained at Spanish universities: Bachelor's Degrees, 3-year Engineering Degrees, and 3-year Architecture Degrees: These are described as "first cycle" courses and they usually have duration of three years. Degrees with Honors, Engineering Degrees and Architecture Degrees: In these courses, after completing the first cycle, students undertake a second, in-depth cycle for specialization in their respective fields and preparation for their professional area. The total duration of these courses is usually four or five years. Doctor: Admission to doctoral studies is only possible for graduates with a degree. Doctoral students must complete a series of courses for two academic years with a minimum of 32 credits ( 320 hours) and present a doctoral thesis, which must be approved. The thesis must be original research into material related to the scientific, technical or artistic field of the doctoral program undertaken by the student. The 


\section{Session S4A}

autonomy of the Spanish universities enables them to organize postgraduate and specialized professional courses, which are extremely important for the completion of a student's academic curriculum and the attainment of a professional specialization. Students who complete these courses obtain the corresponding diploma or university degree [15].

\section{ENGINEERING EdUCATION IN SPAIN}

Trying to modernize the system in operation for decades, the central government issued in 1987 a Decree on Common regulations for University Degrees valid all over the Spanish territory. In the old system almost all the subjects were compulsory and the study programs were substantially equal for all the Faculties/ Schools issuing the same Degree at different Universities.

Some new regulations to put the Spanish system in line with European Higher Education Area (EHEA) have been recently approved. However, the process is still under discussion and under the regulations now in force, some flexibility in the curricula were introduced once the common core, the so called trunk subjects covering around $60 \%$ of the credits, was guaranteed.

Thus, study duration is divided into short- cycle degree courses (3 years, covering a minimum of 180 credits) leading to the award of a Diploma or a Technical Engineering Degree, and long- cycle degree courses (usually 5 years with a minimum of 300 credits) leading to the award of a degree of "Licenciado", Architect or Engineer.

Doctorate or third-cycle studies require 36 credits over a period of 2 years before carrying out the thesis. While first cycles Degrees according to Bologna have not started yet, a certain number of new second cycle programs have been introduced in the last couple of years.

As for the Engineering Education system it is organized as a parallel two first cycle system: Engineer (nominally 5 years) and Technical Engineer (usually lasting 3 years). Mean duration of studies up to graduation is about $40 \%$ higher the quoted values and there is a quite high drop- out rate. Entry requirements are the same for both long and short Degrees, but Technical Engineering studies have a quota reserved for students coming from Professional Education different from "Bachillerato". Graduated Technical Engineers could enter at the 4th of Engineer in the same field of Engineer curricula in limited percentages granting places only to those with the best marks.

Apart from this, there is a reduced number of programs lasting only two years and leading to an Engineer Degree usually on a specialized field. Access is granted to Technical Engineers in similar fields and to students in Science and Engineering after completing three years of study.

Technical Engineering Degrees were traditionally issued by the so called Technical University Schools. More recently, many of these Schools have become Higher Schools and they issuing both Technical Engineering and Engineering Degrees.
In Spain both types of Schools may belong to the same University as it happens in many cases (Technical Universities and many others as the University of Valladolid). By law, both Technical Engineers and Engineers have recognized professional competences and acceptance to the corresponding Technical Engineers and Engineers Councils ("Colegios"). Chartered membership is automatically granted upon request after graduating. Engineers and Technical Engineers Councils try first to maintain the status quo and, if possible, to enlarge their respective fields of operation. In particular Engineering Councils do not favour the extension of a first Degree previous to the Engineer one, the same attitude which is prevalent among Higher Engineering Schools. On the other hand, Technical Engineering Councils support the extension of study programs from 3 to 4 years, which is the length adopted for new first degrees in Spain in accordance to EHEA [16].

\section{FINAL REMARKS}

The spectrum of engineering education texts showed in this paper raises some interest in knowing more about the development of policies and actions in these countries in order to fit to the global educational demands. It is clear the seeking for changing to form the professional engineer for the present labor markets as well as the seeking for the best system in all the countries.

It is possible to notice that even with the colonization process in Iberian America's countries due to the several other sources of influence because of the immigration waves; the fight for excellence is an on going process with peculiar aspects.

The knowledge about these specific situations will contribute for the reflection about engineering education in a larger spectrum not only centered in west north hemisphere regions of the world.

\section{REFERENCES}

[1] Brito, C. da R.; Ciampi, M. M. Forming International Engineers for the Information Society IGIP'2011. In: IGIP International Symposium on Engineering Education, 40, Santos, 2011. Forming International Engineers for the Information Society. Santos: IGIP 2011.

[2] Brito, C. da R.; Ciampi, M. M. The discussions after the Bologna Process in Europe: The Global Engineer. In: American Society for Engineering Education Annual Conference, 118, Vancouver, 2011. Your Passport to Engineering Education. Vancouver: ASEE, 2011.

[3] Brito, C. da R.; Ciampi, M. M. Socio-Ecological Issues Challenging Human Development. In: Safety, Health and Environmental World Congress, 11, Santos, 2011. Socio-Ecological Issues Challenging Human Development. Santos: SHERO, 2011.

[4] Brito, C. da R.; Ciampi, M. M. Engineering Education Inspiring the Next Generation of Engineers. In: International Conference on Engineering and Computer Education, 7, Guimarães, 2011. Engineering Education Inspiring the Next Generation of Engineers. Guimarães: ICECE 2011.

[5] Brito, C. da R.; Ciampi, M. M. Engineers for Global Market: preparing the future. In: SEFI Annual Conference, 39, Lisbon, 2011. Global Engineering Recognition, Sustainability and Mobility. Lisbon: SEFI, 2011.

[6] http://www.dgrhe.min-edu.pt 
Session S4A

[7] http://ec.europa.eu/ploteus/generalinfo renderer.jsp?language=pt\&id= $170443 \&$ type $=\mathrm{ES}$

[8] http://www.academia-engenharia.org/direscrita/ficheiros/ EngineeringEducationPortugal_FinalReport.pdf

[9] http://www.academia-engenharia.org/direscrita/ficheiros/ EngineeringEducationPortugal_FinalReport.pdf

[10] http://www.iadb.org/res/laresnetwork/files/pr294finaldraft.pdf

[11] http://gse.buffalo.edu/org/inthigheredfinance/files/Country_Profiles/L atin_America/Argentina.pdf
[12] http://www.iadb.org/res/publications/pubfiles/pubR-463.pdf

[13] http://www.spainexpat.com/spain/information/schools_and_higher_ed ucation in spain/

[14] http://digital.csic.es/bitstream/10261/17634/1/AR107_1_Achieving\%2 0competence-based $\% 20$ curriculum $\% 20$ in $\% 20$ engineering $\%$ 20education\%20in\%20Spain.pdf

[15] http://www.ineer.org/Events/ICEE2007/papers/370.pdf

[16] http://www.sefi.be/wp-content/abstracts/1221.pdf 